\title{
Against the Grain
}

Volume 22 | Issue 3

Article 47

June 2010

Charleston Conference 2010

Follow this and additional works at: https://docs.lib.purdue.edu/atg

Part of the Library and Information Science Commons

\section{Recommended Citation}

(2010) "Charleston Conference 2010," Against the Grain: Vol. 22: Iss. 3, Article 47.

DOI: https://doi.org/10.7771/2380-176X.5586

This document has been made available through Purdue e-Pubs, a service of the Purdue University Libraries. Please contact epubs@purdue.edu for additional information. 
(Controlled Lots of Copies Keeps Stuff Safe) we work with libraries and publishers in an Open Access environment to keep multiple copies of e-journals and other forms of electronic content on "dark" servers, which can only be accessed when a journal stops being published. I spoke about this sort of library Cloud Computing at our Leadership Institute in Beijing. HKU's Library is one of 11 libraries worldwide to have a CLOCKSS box in which the content is stored.

So, in the future when speaking of clouds, be gentle - most of the intellectual output of everyone in our university is now or will be in the cloud.

Rumors

from page 83

one of our upcoming issues. http://www.timberlinelodge.com/

Oh! Y'all be sure and read the great Forum on this issue, p. 8 \& 10 ! It's about what five prominent librarians (Rick Anderson, Kim Armstrong, Steve Carrico, Tony Horava, and Tony Ferguson) have to say about what they expect from their bookseller! We are interested in doing more Forums on important topics so - let us know if you have a topic to suggest!<kstrauch@comcast.net>

There is so much more to tell you but I am out of space! I am going to put the leftovers on the $\boldsymbol{A} \boldsymbol{T} \boldsymbol{G}$ NewsChannel under Rumors. BTW, have you been to the NewsChannel lately? There has been an interesting exchange there about advertisements on Facebook.

www.against-the-grain.com/

\section{B.O.S.S. \\ Basch Online Subscription Service}

B.O.S.S. is like having your client service representatlive on your desktop!

- VIEW YOUR ACCOUNT INFOAMATION - SEARCH TITLE DATABASE

- TILES ORDERED

- tmes Status

- place ordeas

- place aclaim

- view claims status

- respond to a clam

- puelisher payment

- mVoice information

- downLOAd CUSTOM REPORTS

- view ust of EJoupnals

- address change

- A.Z LISTING ol CONTENT

- offering pubmed unexout FEATURES

- integrateo check-in module

- creation and storage el CUSTOM MWNAGENENT AEPOATS

- access ENOURNULS

- annual renewal online

- receive renewal reminoers 90 DAYS IN ADVANCE

- branded e-portal

- evournal usage summari

H you're tired of getting lost in the crowd, constantly speaking to voicemair and never hearing from your client services representative, move to Basch, where you are our first and only priority

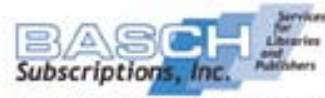

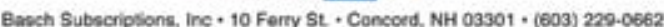
www.basch.com

\section{Conference Theme - Anything Goes!}

Wednesday, November 3, 2010 - Preconferences and Vendor Showcase

Thursday-Saturday, November 4-6, 2010 - Main Conference

Francis Marion Hotel \& Embassy Suites Historic District, Charleston, SC

f you are interested in leading a discussion, acting as a moderator, coordinating a lively lunch, or would like to make sure we discuss a particular topic, please let us know. The Charleston Conference prides itself on creativity, innovation, flexibility,

and informality. If there is something you are interested in doing, please try it out on us. We'll probably love it...

The Conference Directors for the $\mathbf{2 0 1 0}$ Charleston Conference include - Beth Bernhardt, Principal Director (UNCGreensboro) < beth_bernhardt@uncg.edu>, Glenda Alvin<galvin@Tnstate.edu>, Adam Chesler < adam.chesler@cox. net>, Cris Ferguson (Furman University) <cris.ferguson@furman.edu>, David Goodman <dgoodman@princeton.edu>, Chuck Hamaker $<$ cahamake@email.uncc.edu>, Heidi Hoerman $<$ hoerman@sc.edu>, Tony Horava (University of Ottawa)<thorava@uottawa.ca>, Ramune Kubilius (Northwestern Health Sciences Library) <r-kubilius@northwestern.edu>, Corrie Marsh <cmarsh12@hotmail.com>, Heather Miller (SUNY-Albany)<hmiller@uamail.albany.edu>, Jack Montgomery (Western Kentucky University) <jack.montgomery@wku.edu>, Audrey Powers (UFS Tampa Library) <apowers@lib.usf.edu>, John Perry Smith (Total Information Inc.)<jps@totalinformation.com>, Anthony Watkinson (Consultant) <anthony.watkinson@btopenworld.com>, Katina Strauch (College of Charleston) <kstrauch@comcast. net $>$ or www.katina.info/conference.

Send ideas by July 31, 2010, to any of the Conference Directors listed above.

Or to: Katina Strauch, MSC 98, The Citadel, Charleston, SC 29409

843-723-3536 (voice) 843-805-7918 (fax) 843-509-2848 (cell)

<kstrauch@comcast.net> http://www.katina.info/conference

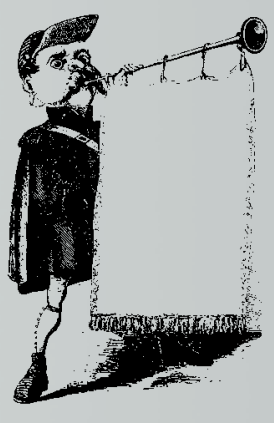

